\title{
Influence of summer dung deposition on estimated yellow bristle grass (Setaria pumila) seed production
}

\author{
P.J. Gerard ${ }^{1}$, A.F.B. Cook $^{2}$ and D.J. Wilson ${ }^{1}$ \\ ${ }^{1}$ AgResearch, Ruakura Research Centre, Private Bag 3123, Hamilton, New Zealand \\ ${ }^{2}$ Edinburgh Road, Hillcrest, Hamilton, 3216, New Zealand \\ Corresponding author: pip.gerard@agresearch.co.nz
}

\begin{abstract}
A study was carried out to investigate the impact of dung pats on seeding by yellow bristle grass (Setaria pumila). Fresh cow dung was placed on dairy pasture as uniform pats in summer at two sites in Waikato, New Zealand, and changes in pasture attributes and earthworm abundance monitored over three grazing rotations. A zone of repugnance, where dairy cows avoided grazing, formed out to $40 \mathrm{~cm}$ from the centre of the pat. It was still evident at 60 days. The site with highest yellow bristle grass incidence had taller and bigger yellow bristle grass seed heads in the zone, resulting in over twice as much seed as control pasture. Earthworm abundance was markedly higher under dung than control pasture, the main species being Aporrectodea caliginosa. On-farm management strategies that may accelerate the return of the zone of repugnance to full utilization by stock and minimise weed exploitation are discussed.
\end{abstract}

Keywords dung, yellow bristle grass, Setaria pumila, earthworms.

\section{INTRODUCTION}

New Zealand pastoral farm systems are based on exotic forage species and grazing animals, predominantly from Europe. However, our pastoral ecosystems have a relatively low diversity of the primary decomposers essential to incorporate the large amount of dung produced back into the soil. We depend on earthworms (Aporrectodea spp., Lumbricus spp., Octolasion spp.), and all are accidental introductions, so their distribution is patchy, with large areas of farmland lacking the deep burrowing species $L$. terrestris and A. longa (Schon et al. 2011). The Dung Beetle Release Strategy Group and Landcare Research have recently obtained permission to release 11 new species of dung beetle into New Zealand as current species are ineffective (Dymock 1993) (S.A. Forgie, Landcare Research, personal communication).
Fouling by dung can result in wastage in dairy pasture utilisation. The average cow produces an estimated 15 pats a day (Maclusky 1960) and in $24 \mathrm{~h}$ at a grazing density of 75 cow/ha (Moir et al. 2011) this equates to around 1125 pats/ha. Williams \& Haynes (1995) estimated that $6 \%$ of dairy pasture is covered by dung in a year. In a typical rotationallygrazed New Zealand pasture, the herbage around each of these pats forms a zone of repugnance that is rejected by grazing cattle for four grazings (5-6 months) before the height is returned to that of surrounding pasture (Weeda 1967).

Observations suggest these repugnance zones act as loci for weeds. Seeds of undesirable plants ingested by grazing animals can establish in their dung pats in new pastures (Burggraaf \& Thom 2002; Harrington et al. 2011). But do repugnance 
zones also accelerate weed proliferation within established pasture? This paper reports on a study on two Waikato farms infested with yellow bristle grass (Setaria pumila (Poir.) Roem. \& Schult., Poaceae). Yellow bristle grass is summer-active with seed heads appearing in late December (Tozer et al. 2008). While readily grazed in its vegetative state, it is avoided by stock once seed heads appear. It was hypothesised that the protection provided by the zone of repugnance around dung pats would favour seed production by this invasive species.

\section{METHODS}

The study was undertaken in summer 2011/12 on two intensive dairy farms (Site 1 and Site 2) near Te Awamutu. The experimental design comprised 16 replicates of two treatments (dung pat and a control with no dung) at each site, arranged in a randomised linear design with $4 \mathrm{~m}$ long plots along two transects. Based on previously published methods (Williams \& Haynes 1995), fresh cow dung was collected, mixed thoroughly, and $1.6 \mathrm{~kg}$ applied to an area of $530 \mathrm{~cm}^{2}$ in the centre of each plot using a $26 \mathrm{~cm}$ diameter cardboard ring as a guide. Each site was set up in December shortly after grazing and a plot was not used if an existing dung pat was already present. The resident pre-trial earthworm population was sampled by taking ten $10 \mathrm{~cm}$ diameter soil cores to a depth of $10 \mathrm{~cm}$ from each site and sorting by hand. Changes in earthworm abundance were estimated by taking a $10 \mathrm{~cm}$ diameter soil core from each of four randomly selected dung pats/site and controls at 10, 20, 40 and 60 days after dung application. Sampled pats and controls were excluded from subsequent selections as sampling would have altered pat dynamics. The soil was sorted in situ and replaced.

Measurements were made for three grazings after the experiment had been set up. Grazing intervals at Site 1 varied with pasture growth and ranged from 20 days for Grazing 2 to 14 days for Grazing 3, while at Site 2 there was less variation (19-21 days). The day (or sometimes 2 days) before and after each grazing, pasture height and composition were compared in the dung and control plots. A point analysis apparatus was used to assess the presence of grass, clover, broad-leafed weeds or bare ground at $5 \mathrm{~cm}$ intervals over two $50 \mathrm{~cm}$ transects commencing in the centre of the dung and going left and right along the line of the plot. Pasture height was measured at each interval.

The persistence of long pasture in the zone of repugnance through three grazings is likely to be a combination of several factors from the repugnance of dung, older less palatable grass, and better plant growth through increased soil fertility and earthworm activity. Therefore the differences in pasture ingested were calculated from the pasture height data at the three grazings as follows: (pre-grazing control - post-grazing control) (pre-grazing dung - post-grazing dung).

Point analysis was continued on cored pat plots, avoiding the segment from which the core was taken. Following the final pasture assessment, yellow bristle grass seeding was assessed (14 and 20 February 2012 for Sites 1 and 2 respectively). A $30 \times 30 \mathrm{~cm}$ quadrat was placed immediately adjacent to the centre of each plot and all herbage within the plot cut at ground level and placed in labelled bags. Yellow bristle grass stalks bearing mature seed heads in each sample were removed, counted and the length of each stalk and seed head measured. The amount of seed was calculated by combining head density and the following direct relationship: seeds/head $=$ $26 \times$ head length $(\mathrm{cm})-0.6\left(\mathrm{R}^{2}=76\right)(\mathrm{K} . \mathrm{N}$. Tozer, AgResearch, unpublished data). A soil fertility test at each site was also undertaken at this time.

The plant data were analysed using REML. Square-root transformation was used where appropriate but the untransformed means and SEDs are presented. The earthworm data were analysed by ANOVA.

\section{RESULTS}

The presence of dung had a marked influence on post-grazing height measurements at all three grazings assessed, and the area influenced increased with time, being significantly different from the control plots out to $40 \mathrm{~cm}$ at the final grazing (Figure 1). At Grazing 1, pasture under the dung was smothered, therefore shorter than 
the control. Beyond that, the pasture had a clear hump near the dung that diminished with increasing distance, the zone of repugnance. While pasture was growing through the pats at Grazings 2 and 3, it is clear that the zone was still not being grazed down to the level of the control plots (Figures $1 \mathrm{~b} \& 1 \mathrm{c}$ ).

It was shown that while pasture out to $35 \mathrm{~cm}$ in the zone was repugnant to grazing animals at Grazing 1, it was only repugnant immediately above the pat at the subsequent two grazings (Figure 2). In fact, the negative indices shown in Figure 2 suggest that at Grazings 2 and 3 more pasture was ingested on the zone than controls.
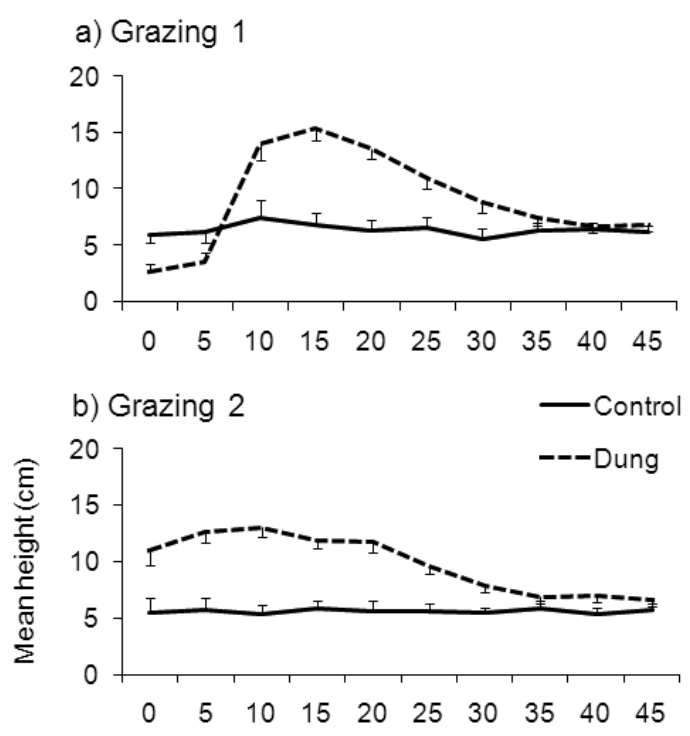

c) Grazing 3

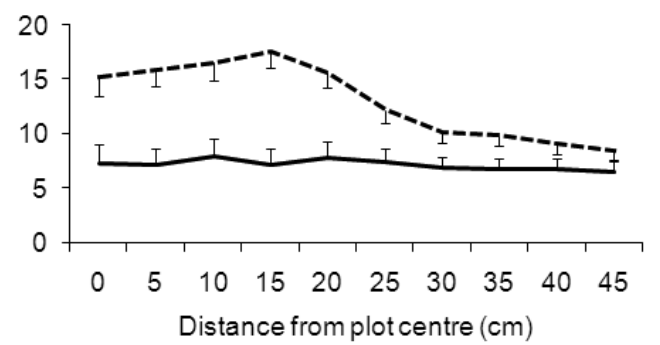

Figure 1 Mean post-grazing pasture height of control and dung plots at $5 \mathrm{~cm}$ intervals from the centre of the plot (and dung pat) at the first three grazings following deposition. Error bars denote SED.

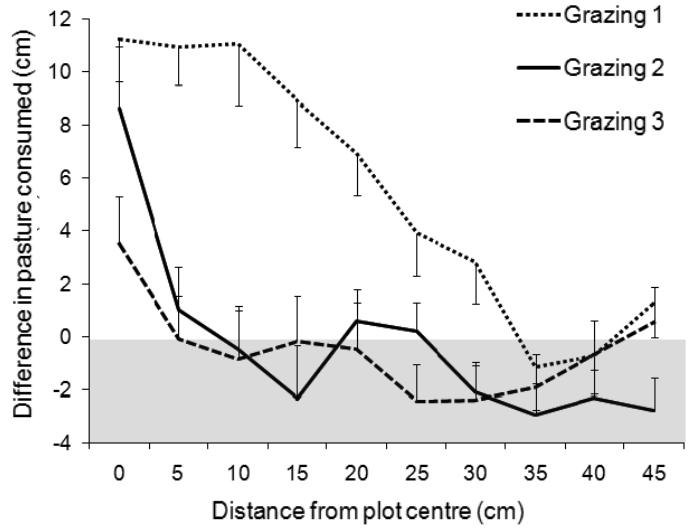

Figure 2 Difference between control and dung plots in mean pasture consumed at varying distances from plot centre at three grazing episodes.

The two sites varied greatly in pasture composition, with Site 1 having markedly more clover $(24 \%$ versus $2 \% ; \mathrm{P}<0.001)$, more bare ground ( $4 \%$ versus $0 \% ; \mathrm{P}<0.001)$ and fewer broadleaf weeds ( $8 \%$ versus $13 \% ; \mathrm{P}<0.03)$ than Site 2 in overall pre-grazing assessments. The area covered by dung dropped significantly over the three grazings from an overall $10 \%$ of the area sampled after Grazing 1 to $0.2 \%$ after Grazing 3 $(\mathrm{P}<0.001)$. There was a Site $\times$ Grazing interaction in dung area $(\mathrm{P}<0.003)$ as dung decomposed more rapidly at Site 1 than Site 2 .

Soil tests showed no nutrient deficiencies. Both sites were $\mathrm{pH} 6.4$ and Site 1 had much higher levels of Olsen phosphate (59 vs $38 \mathrm{P} \mathrm{m} / \mathrm{ml}$ ) and potassium (24 vs 14 MAF QT) than Site 2.

The presence of dung had a large impact on yellow bristle grass seed at Site 2, but only a small and statistically insignificant impact at Site 1 (Table 1). At Site 2, plants in the dung plots were visibly more vigorous, and produced seed heads that were both taller and longer compared to controls. This resulted in an estimate of over twice as much seed produced on the dung plots compared to the control plots.

The majority ( $95 \%$ ) of earthworms recovered were Aporrectodea caliginosa, followed by Lumbricusterrestis. Initial earthworm populations 
Table 1 Mean abundance and length of yellow bristle grass seed stalks, the length of the seed heads and estimated seed production for control and dung treatments at two sites.

\begin{tabular}{lcccc}
\hline & No. stalks $/ \mathrm{m}^{2}$ & Stalk length $(\mathrm{cm})$ & Head length $(\mathrm{cm})$ & Seeds $/ \mathrm{m}^{2}$ \\
\hline Site 1 - Control & 48 & 11.6 & 2.74 & 4600 \\
Site 1 - Dung & 51 & 12.5 & 2.81 & 5530 \\
Site 2 - Control & 308 & 11.6 & 1.97 & 16100 \\
Site 2 - Dung & 478 & 19.3 & 2.77 & 33820 \\
P-values: & & & & \\
Treatment & 0.063 & $<0.001$ & $<0.001$ & 0.007 \\
Site & 0.024 & 0.11 & 0.204 & 0.067 \\
Site $\times$ Treatment & 0.110 & 0.002 & 0.012 & 0.027 \\
\hline
\end{tabular}

were highest at Site 2 at trial commencement $(\mathrm{P}<0.01)$ (Figure 3), but as Waikato soil moisture levels varied markedly when they were sampled (e.g. $33 \%$ vs $41 \%$ at Ruakura (National Climate database http://cliflo.niwa.co.nz)), the difference may have arisen because the soil cores taken were only to $10 \mathrm{~cm}$ and earthworms may have been deeper in the drier soil. There was little change at Day 10 at Site 1 but over the period from 20-60 days after dung deposition, earthworms were markedly higher under dung pats compared to control plots $(\mathrm{P}<0.0001)$ and reached higher levels at Site 1 than at Site $2(\mathrm{P}<0.01)$.

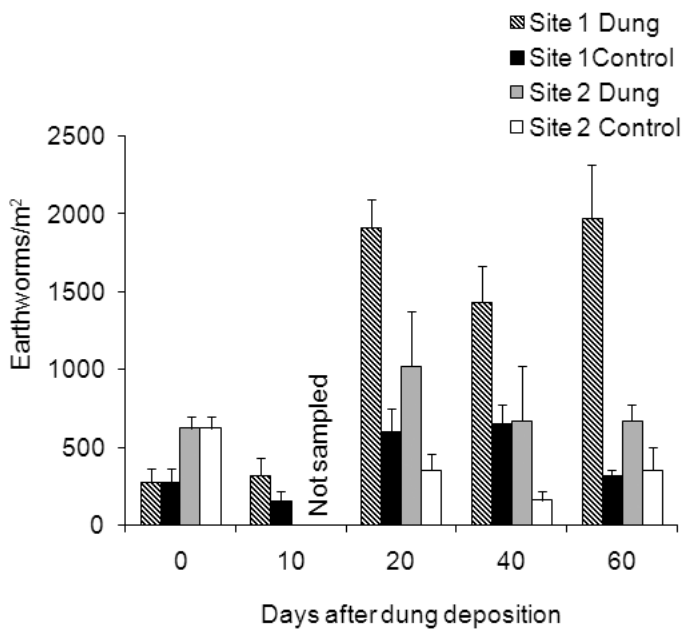

Figure 3 Summer earthworm density (numbers $/ \mathrm{m}^{2}$ ) under dung and in control plots at two Waikato sites in the 60 days following dung deposition.

\section{DISCUSSION}

The results from this study confirm previous research demonstrating that cattle avoid grazing near dung pats and the subsequent formation of the zone of repugnance (Weeda 1967, 1977; Hypolite et al. 1984; Williams \& Haynes 1995; Burggraaf et al. 2009). The present research also provided evidence that dung repugnance disappears for the most part by the second grazing as more pasture was consumed in the dung patch than control plots. Therefore it is likely that zones persist through the combination of new foliage stimulated by the heightened soil fertility and the rejection of old plant material by stock. Furthermore, Maclusky (1960) observed that maturation and flowering of forage plants in the vicinity of the dung pat adds to stock rejection and patch persistence. The presence of the barbed yellow bristle grass seed heads would further accentuate avoidance behaviour, as would other unpalatable weed species, such as thistles.

The combination of selective avoidance of pasture in the zone and additional nutrients appears to enhance the yellow bristle grass seed head abundance and length. The size of the response will vary with site as demonstrated by the differences between Sites 1 and 2. Tozer et al. (2008) showed pasture management is important, and identified that yellow bristle grass cover was negatively associated with Olsen $\mathrm{P}$, post-grazing residual dry matter and $\mathrm{pH}$. Site 1 had a very high Olsen $\mathrm{P}$ and much lower yellow bristle grass abundance in control plots than Site 2 and these data match well with that of the 
above authors. Similarly, there was low pressure on the weed by stock at Site 2 due to excellent growing conditions in January 2012. While the grazing interval was reduced to 15 days at Site 1 to ensure good pasture utilisation, it remained at 20 days at Site 2. This is reflected in the higher overall mean pasture length in the control plots at Grazing 3 (Figure 1). Finally, although both farms had a relatively high soil $\mathrm{pH}$ of $6.4, \mathrm{pH}$ is reduced under dung (Aarons et al. 2004), benefiting nearby yellow bristle grass plants.

Apart from the role of dung deposition in weed seed dispersal and establishment, there is little published research on repugnance zones and how they augment within-paddock weed reproduction and invasion. The present research has shown that the zone of repugnance can enhance both the height and abundance of yellow bristle grass seed stalks and the size of the seed head. All these attributes will increase the ability of the weed to spread. The same repugnance factors that enhance yellow bristle grass spread may also enhance the spread of other weeds, especially unpalatable species.

What management practices can be implemented to reduce the impact of loss of pasture from cow pats? The first strategy could be to accelerate dung decomposition so that most has disappeared by the next grazing. It is anticipated that the addition of effective dung beetles to New Zealand dairy pasture fauna will greatly assist rapid dung burial, especially the species that prefer fresh dung. At present, earthworms are New Zealand's primary dung decomposers. Indeed, more earthworms were present under the dung at Site 1, corresponding to faster breakdown of dung and smaller yellow bristle grass response than at Site 2. However, with lowest earthworm densities normally found in midsummer (Prestidge et al. 1997) when dung decomposition in non-irrigated pastures is slow (Weeda 1967), summer-active dung beetle species are expected to benefit dung decomposition during the drier months. The difference between the sites in earthworm activity is likely to be due to Site 1 clover content: it is known that white clover enhances earthworm abundance and burrowing (Eekeren et al. 2009). Therefore ensuring dung-burying earthworm species are present and good pasture clover content will aid decomposition. The 2011/2012 summer in the Waikato region was unusually wet $(165 \%$ above normal rainfall) and overcast (lowest sunshine hours on record) (NIWA 2012). Therefore the topsoil species, such as A. caliginosa, which usually aestivate in summer, remained active throughout the study period.

The other strategy to accelerate the return of the zone of repugnance to "normal" pasture is the removal of the rank material at the time of the first grazing after dung deposition. On mixed stock farms, grazing by sheep or deer after cattle reduced patch size (Trotter et al. 2006) and an increased grazing intensity has been associated with smaller patches with cattle alone (Weeda 1967). However, this may not be effective when unpalatable weeds, such as yellow bristle grass, are exploiting the zone of repugnance. The use of post-grazing mowing of zones should be investigated in intensive dairy systems to ascertain the benefits this may provide in utilisable pasture and slowing of weed ingress in permanent pastures.

\section{ACKNOWLEDGEMENTS}

This paper is based on a summer student project undertaken by Asher Cook through the BayerBoost Environmental Scholarship Scheme. The authors thank Bayer New Zealand Ltd for its support and also the Royal Society of New Zealand who administers the BayerBoost scholarship. We also thank Catherine Cameron for the statistical analyses and the two Yellow Bristle Grass Action Group farmers who provided us the sites and good communication essential to the project.

\section{REFERENCES}

Aarons SR, O'Connor CR, Gourley CJP 2004. Dung decomposition in temperate dairy pastures. I. Changes in soil chemical properties. Australian Journal of Soil Research 42: 107-114.

Burggraaf VT, Thom ER 2002. Minimising endophyte contamination from ryegrass seed in cow dung. Proceedings of the New Zealand Grassland Association 64: 97-101. 
Burggraaf VT, Boom CJ, Sheath GW, Brooky AR 2009. The effect of rotational grazing by either calves, cows, lambs or ewes on the removal of herbage contaminated with gastro-intestinal parasite larvae around cattle faecal pats. New Zealand Journal of Agricultural Research 52: 289-297.

Dymock JJ 1993. A case for the introduction of additional dung-burying beetles (Coleoptera: Scarabaeidae) into New Zealand. New Zealand Journal of Agricultural Research 36: 163-171.

Eekeren Nv, Liere Dv, Vries Fd, Rutgers M, Goede Rd, Brussaard L 2009. A mixture of grass and clover combines the positive effects of both plant species on selected soil biota. Applied Soil Ecology 42: 254-263.

Harrington KC, Beskow WB, Hodgson J 2011. Recovery and viability of seeds ingested by goats. New Zealand Plant Protection 64: 7580.

Hypolite G, Morhain B, Vignon B 1984. Effect of dung and urine patches of a dairy herd on the production, composition and intake of grass. Bulletin Technique, Centre de Recherches Zootechniques et Veterinaires de Theix 58: 11-17.

Maclusky DS 1960. Some estimates of the areas of pasture fouled by the excreta of dairy cows. Journal of the British Grassland Society 15: 181-188.

Moir JL, Cameron KC, Di HJ, Fertsak U 2011. The spatial coverage of dairy cattle urine patches in an intensively grazed pasture system. Journal of Agricultural Science 149: 473-485.
Prestidge RA, Marshall SL, Thom ER 1997. Seasonal earthworm densities on endophyteinfected and endophyte-free perennial ryegrass. Proceedings of the 50th New Zealand Plant Protection Conference: 73-77.

NIWA 2012. Summer 2011-2012 Climate summary. http:/www.niwa.co.nz/sites/ default/files/climate_summary_summer_ 2011_2012_final.pdf (accessed 4 April 2012).

Schon NL, Mackay AD, Gray RA, Minor MA 2011. Earthworms in New Zealand sheepand dairy-grazed pastures with focus on anecic Aporrectodea longa. Pedobiologia 54: 131-137.

Tozer KN, James TK, Cameron CA 2008. Botanical and management factors associated with Setaria pumila abundance: implications for pasture management. New Zealand Plant Protection 61: 121-126.

Trotter CG, Nicol AM, Ridgway MJ 2006. Sheep and deer grazing of pasture close to cattle dung pats. Proceedings of the New Zealand Society of Animal Production 66: 59-63.

Weeda WC 1967. The effect of cattle dung patches on pasture growth, botanical composition, and pasture utilisation. New Zealand Journal of Agricultural Research 10: 150-159.

Weeda WC 1977. Effect of cattle dung patches on soil tests and botanical and chemical composition of herbage. New Zealand Journal of Agricultural Research 20: 471-478.

Williams PH, Haynes RJ 1995. Effect of sheep, deer and cattle dung on herbage production and soil nutrient content. Grass and Forage Science 50: 263-271. 